\title{
IMPULSIVE AND REFLECTIVE STUDENTS' UNDERSTANDING TO LINEAR EQUATIONS SYSTEM: AN ANALYSIS THROUGH APOS THEORY
}

\author{
Dinda Ayu Rachmawati \\ Mathematics Education, Faculty of Mathematics and Natural Science, Universitas Negeri Surabaya \\ $e$-mail : dindarachmawati16030174005@mhs.unesa.ac.id \\ Tatag Yuli Eko Siswono \\ Mathematics Education, Faculty of Mathematics and Natural Science, Universitas Negeri Surabaya \\ $e$-mail : tatagsiswono@.unesa.ac.id
}

\begin{abstract}
Understanding is constructed or reconstructed by students actively. APOS theory (action, process, object, schema) is a theory that states individuals construct or reconstruct a concept through four stages, namely: action, process, object, and scheme. APOS theory can be used to analyze understanding of a mathematical concept. This research is a qualitative research which aims to describe impulsive and reflective students' understanding to linear equations system based on APOS theory. Data collection techniques were carried out by giving Matching Familiar Figure Test (MFFT) and conceptual understanding tests to 32 students of $8^{\text {th }}$ grade in junior high school, then selected one subject with impulsive cognitive style and one subject with reflective cognitive style that can determine solutions set and solve story questions of linear equation system of two variables correctly, then the subjects were interviewed. The results show that there were differences between impulsive and reflective subjects at the stage of action in explaining the definition and giving nonexamples of linear equation system of two variables, show the differences in initial scheme of two subjects. At the process stage, impulsive and reflective subjects determine solutions set of linear equation system of two variables. At the object stage, impulsive and reflective subjects determine characteristics of linear equation system of two variables. At the schema stage, impulsive and reflective subjects solve story questions of of linear equation system of two variables, show the final schematic similarity of two subjects.
\end{abstract}

Keywords: understanding, APOS theory, linear equations system of two variables, impulsive cognitive style, reflective cognitive style.

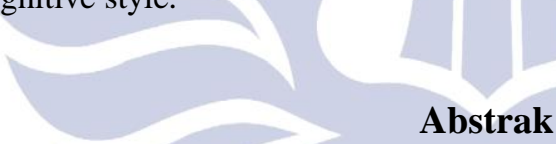

Pemahaman dikonstruksi atau direkonstruksi sendiri oleh siswa secara aktif. Teori APOS (aksi, proses, objek, skema) adalah suatu teori yang mengemukakan bahwa individu mengkonstruk atau merekonstruksi suatu konsep melalui empat tahap yaitu: aksi, proses, objek, dan skema. Teori APOS dapat digunakan untuk menganalisis pemahaman mengenai suatu konsep matematika. Penelitian ini adalah penelitian kualitataif yang bertujuan mendeskripsikan pemahaman konsep sistem persamaan linear dua variabel pada siswa bergaya kognitif impulsif dan reflektif. Teknik pengumpulan data dilakukan dengan pemberian Matching Familiar Figure Test (MFFT) dan tes pemahaman konsep terhadap 33 siswa SMP di Gresik, selanjutnya dipilih satu subjek dengan gaya kognitif impulsif dan satu subjek dengan gaya kognitif reflektif yang dapat menentukan himpunan penyelesaian dan menyelesaikan soal cerita SPLDV dengan benar. Hasil penelitian menunjukkan ada perbedaan antara subjek impulsif dan reflektif pada tahap aksi dalam menjelaskan definisi dan memberikan non contoh SPLDV, menunjukkan adanya perbedaan skema awal kedua subjek. Pada tahap proses, subjek impulsif dan reflektif menentukan himpunan penyelesaian SPLDV. Pada tahap objek, subjek impulsif dan reflektif menentukan karakteristik SPLDV. Pada tahap skema, subjek impulsif dan reflektif menyelesaikan soal cerita SPLDV, menunjukkan adanya persamaan skema akhir kedua subjek.

Kata Kunci: pemahaman, teori APOS, sistem persamaan linear dua variabel, gaya kognitif impulsif, gaya kognitif reflektif.

\section{INTRODUCTON}

Students should understand mathematical concepts. Piaget (1974) states that understanding is constructed or reconstructed by students actively. Therefore, the concepts that have been constructed by students in previous learning will continue to be used in future learning. Students who are able to reconstruct previously constructed concepts will find it easy to use these concepts in future learning. However, when students are unable to reconstruct concepts 
that they have understood, students will have difficulty in reusing the concepts when needed.

APOS theory (action, process, object, schema) is a theory that states that individuals construct or reconstruct a concept through four stages, namely: action, process, object, and scheme (Dubinsky, 2000). Dubinsky (2000) argues that the understanding of a mathematical concept is the result of the construction or reconstruction of mathematical objects through mathematical actions, processes, and objects which are organized in a scheme. Students' mathematical understanding ability can be seen from APOS theory.

Dubinsky and McDonald (2001) state that action in APOS theory is a transformation from mathematics objects that carry out by an individual through step by step procedure and operation. When an action is repeated and the individual reflects to the action, then he/she can form internal mental construction. This calls as Process. An Object is constructed from a process when the individual realized that process as a totality and could transform on it. Finally, schema is sets of Actions, Processes, Objects, and other schemas that individual have relate on mathematics problem situation.

Dubinsky (2000) states that APOS theory also fulfills 6 characteristics, one of which is having a wide range of phenomena. So this APOS theory can be used for a number of mathematical topics and various levels of education. According to Dubinsky (2000), APOS theory can be used in Algebra topics. From these results, in this study using material that is within the scope of algebra is linear equation system of two variables. Students' conceptual understanding of linear equation system of two variables is still relatively low (Kurniawati et al, 2018).

Students' conceptual understanding is influenced by several factors, external and internal factors. External factor that influence students understanding is the way teachers teach material. Internal factor is the cognitive styles of students. Uno (2006) states that cognitive style refers to a people cognitive processes related to understanding, knowledge, perception, thoughts, imagination. Furthermore, Abubakar (2016) states that cognitive styles is a characteristic of every individual in paying attention and understanding information and interpreting a situation. Impulsive and reflective cognitive styles are type of cognitive styles based on the time of understanding a concept. In addition, Desmita (2009) also denotes that impulsive students are students who respond very quickly but also make many mistakes in the process. Conversely, students with reflective styles tend to use more time to respond and reflect on the accuracy of answers.

Based on the description above, the researchers aim to conduct research on impulsive and reflective students' understanding to linear equations system based on APOS theory.

\section{METHODS}

The research approach is qualitative research which aims to describe impulsive and reflective students' understanding to linear equations system based on APOS theory. The research data consisted of three data, namely (1) the results of the MFFT, (2) the results of the conceptual understanding test, and (3) the results of the interview.

Data collection techniques were carried out by giving Matching Familiar Figure Test (MFFT) and concept understanding tests to 32 students of $8^{\text {th }}$ grade in junior high school, then selected one subject with impulsive cognitive style and one subject with reflective cognitive style that can determine solutions set and solve story questions of linear equation system of two variables correctly, then the subjects were interviewed. Concept understanding tests result data from the research subjects were analyzed by referring to the indicators of students' understanding to linear equations system based on APOS theory. Interview data were analyzed by researchers using qualitative analysis techniques, the stages of data reduction, data presentation, and drawing conclusions. Triangulation was conducted by increase perseverance such as check questions, read various book references, research results, and documentation related to this research.

To facilitate the presentation of interview data, researchers used the indicators which created by researcher in the following table.

Table 1. Indicators

\begin{tabular}{|c|l|}
\hline $\begin{array}{c}\text { Stage of } \\
\text { APOS } \\
\text { Theory }\end{array}$ & \multicolumn{1}{|c|}{ Indicators } \\
\hline \multirow{2}{*}{ Action } & $\begin{array}{l}\text { Restate the concept of linear equation } \\
\text { system of two variables }\end{array}$ \\
\cline { 2 - 3 } & $\begin{array}{l}\text { Determining examples and non examples } \\
\text { of linear equation system of two variables }\end{array}$ \\
\cline { 2 - 3 } & $\begin{array}{l}\text { Determining a certain value is solutions } \\
\text { set of linear equation system of two } \\
\text { variables or not }\end{array}$ \\
\hline Process & $\begin{array}{l}\text { Determining solutions set of linear } \\
\text { equation system of two variables }\end{array}$ \\
\hline Object & $\begin{array}{l}\text { Determining characteristics of linear } \\
\text { equation system of two variables based on } \\
\text { solutions set }\end{array}$ \\
\hline \multirow{2}{*}{ Schema } & $\begin{array}{l}\text { Changing verbal sentences into } \\
\text { mathematical sentences on linear equation } \\
\text { system of two variables story question }\end{array}$ \\
\hline
\end{tabular}


Use certain procedures in solving linear equation system of two variables story question

\section{RESULTS}

The result of this research describes impulsive and reflective students' understanding to linear equations system based on APOS theory consisting of action stage, process stage, object stage, and schema stage. The following is a task of concept understanding tests given to the research subjects.

1. a) What is the definition of linear equation system of two variables?

b) Write the general form of linear equation system of two variables and give information!

2. Determine the solutions set!
a) $2 x-4 y=12$
$9 \mathrm{x}+6 \mathrm{y}=18$
b) $3 \mathrm{x}-2 \mathrm{y}=12$
$9 \mathrm{x}-6 \mathrm{y}=18$
c) $6 x+5 y=30$
$36 x+30 y=180$

3. Mother and Aunt shop at the same store. Mother bought $3 \mathrm{~kg}$ of eggs and $6 \mathrm{~kg}$ of sugar for Rp. 147,000.00. While Auntie bought $5 \mathrm{~kg}$ of eggs and $9 \mathrm{~kg}$ of sugar for $\mathrm{Rp} 233,000.00$. Determine the price of $4 \mathrm{~kg}$ of eggs and $8 \mathrm{~kg}$ of sugar!

\section{Case 1 - Impulsive Subject}

\section{a. Action Stage}

Based on the results of the answer sheets, then analyzed by interview can be seen that subject explains definition of linear equation system of two variables incorrectly. This is relevant to the study of Juliana and Jafar (2017) that students have difficulty when defining linear equation system of two variables. Subject explains the general form of the concept with the information correctly, but the letters used in general form is not coherent. This is in line to the study of Warli (2010) that impulsive subjects act without much thought beforehand and spontaneous. Subject explains definition of linear equation system of two variables incorrectly. This is relevant to the study of Juliana and Jafar (2017) that students have difficulty when defining linear equation system of two variables. Subject explains the general form of the concept with the information correctly, but the letters used in general form is not coherent. This is in line to the study of Warli (2010) that impulsive subjects act without much thought beforehand and spontaneous. Subject determines example and non example correctly, but initially the subject was confused to determine non examples which means needs help to understand the concept deeper. Subject determines a value is solution of linear equation system of two variables or not and give a reason correctly. This is relevant to the study of Parraguez and Asuman (2009) that the action stage is when someone can show calculations and transformations of mathematical objects, such as substituting number variables in formulas.

Table 2. Impulsive Subject Answer at Action Stage

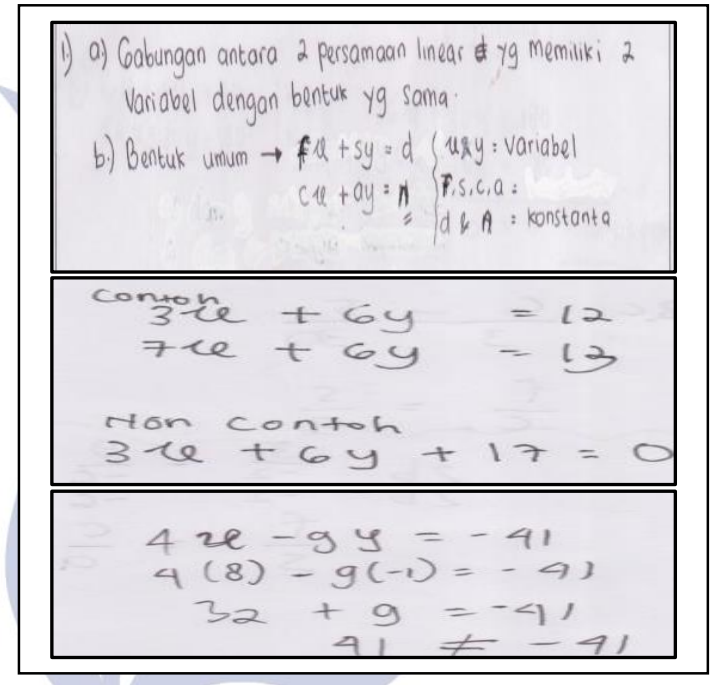

$P \quad$ : What do you know about the definition of linear equation system of two variables?

SIM : Linear equation system of two variables are combination of 2 linear equations that have 2 variables with the same shape,

$P$ : What term of coefficients?

SIM : Cannot be zero.

$P \quad:$ All variables, coefficients, and constants in linear equation system of two variables are number?

SIM : Real number.

$P \quad:$ Give example and non example from linear equation system of two variables?!

SIM : $3 x+6 y=12 \ldots$ (1)

$7 x+6 y=13 \ldots(2)$

I am confused about non example.

$P \quad$ : You already understand the general form of linear equation system of two variables, so what about non example?

SIM : It means not same as form of linear equation system of two variables, so non example is $3 x+6 y+17=0$.

$P \quad:$ Are $(8,-1)$ the solution set of

$4 x-9 y=-41 \ldots(1)$

$3 x-4 y=20 \ldots(2) ?$

SIM : $4(8)-9(-1)=-41$

$32+9=41$

$-41 \neq 41$

So, not solution. 
From the description above, it can be seen that the initial scheme subject about linear equation system of two variables concept are explains definition incorrectly, explains general form with the information and conditions correctly, determines example correctly and non example incorrectly.

\section{b. Process Stage}

Based on the results of the answer sheets, then analyzed by interview can be seen that subject determines and explains solutions set of linear equation system of two variables correctly used the elimination method. This is relevant to the study of Dubinsky and McDonald (2001) that on process stage occurs when an individual reflexes in taking action, he can pass step by step in his thinking.

Table 3. Impulsive Subject Answer at Process Stage

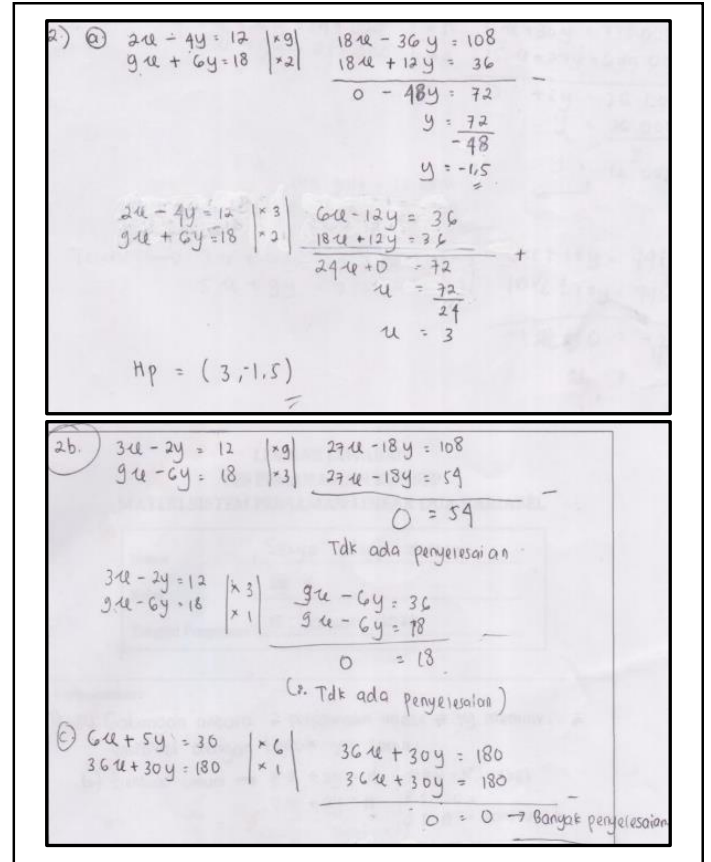

$P \quad$ : How to determine solution set for question number $2 a$ ?

SIM : Used the elimination method. The number of $x$ is 3 , the number of $y$ is $-1 \frac{1}{2}$. So the solution set is $\left(3,-1 \frac{1}{2}\right)$.

$P \quad:$ How to determine solution of question number $2 b$ ?

SIM : Used the graph method, because initially I used the elimination method and the result is $0=18$, which means there is no solution, then I doubt my calculations might be wrong, finally I used the graph method and the graphs are parallel, so there is no solution set.

$P \quad$ : How to determine solution set of question number $2 a$ ?

SIM : Used the elimination method, but the answer I got was precisely $0=0$, so there are many solutions sets.

\section{c. Object Stage}

Based on the results of the answer sheets, then analyzed by interview can be seen that subject determines the graphic form of each linear equation system of two variables incorrectly based on the solutions set. Subject was initially confused to determines the characteristics of each linear equation system of two variables based on the solutions set. Subject also did not know if solution was affected by comparison of coefficients in each linear equation system of two variables, after explained, finally subject could make a comparison coefficients based on general form of linear equation system of two variables.

Table 4. Impulsive Subjects Answer at Object Stage

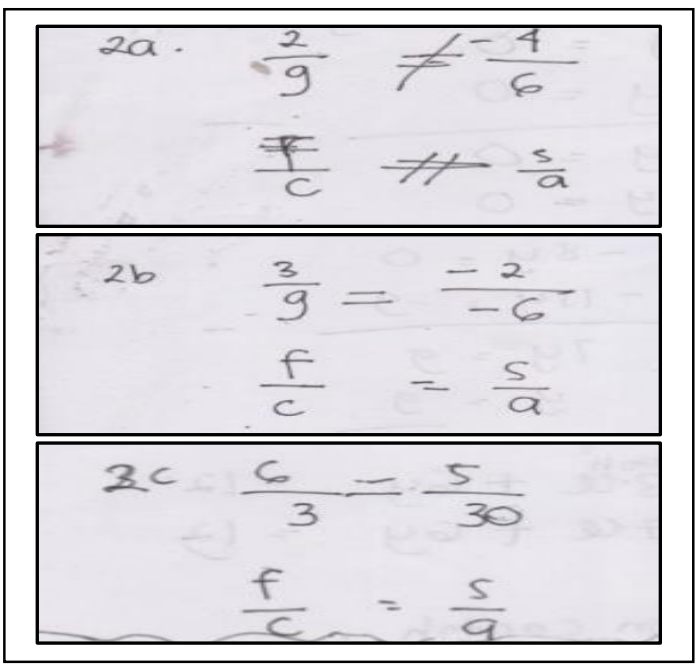

$P \quad$ : What is the conclusion of each linear equation system of two variables characteristic for questions numbers $2 a, b, c$ ?

SIM : If linear equation system of two variables have one solution set so the graph intersects and applies $\frac{f}{c} \neq \frac{s}{a}$. if linear equation system of two variables don't have solution set so the graph is parallel and applies $\frac{f}{c}=\frac{s}{a}$, if linear equation system of two variables have many solutions sets so the graph coincides and applies $\frac{f}{c}=\frac{s}{a}$.

Subject determines the characteristics of each linear equation system of two variables for numbers $2 \mathrm{a}$, b, c based on solutions set, graphical form, and coefficients comparison.

\section{d. Schema Stage}

Based on the results of the answer sheets, then analyzed by interview can be seen that subject changes verbal sentence that is known in story question into a mathematical sentence, but forgets to think about what is $\mathrm{x}$ and $\mathrm{y}$, after interviews subject could think of $\mathrm{x}$ and $y$ correctly, subject also forgets to write what is asked at the problem becomes a mathematical sentence, after interviews subject could make a mathematical sentence about what is asked. Subject used elimination method 
from mathematical model to determine price of $1 \mathrm{~kg}$ of sugar and $1 \mathrm{~kg}$ of eggs then determine price of $4 \mathrm{~kg}$ of sugar and $8 \mathrm{~kg}$ of eggs. Subject looks less detailed in solving the story question.

Table 5. Impulsive Subject Answer at Schema Stage

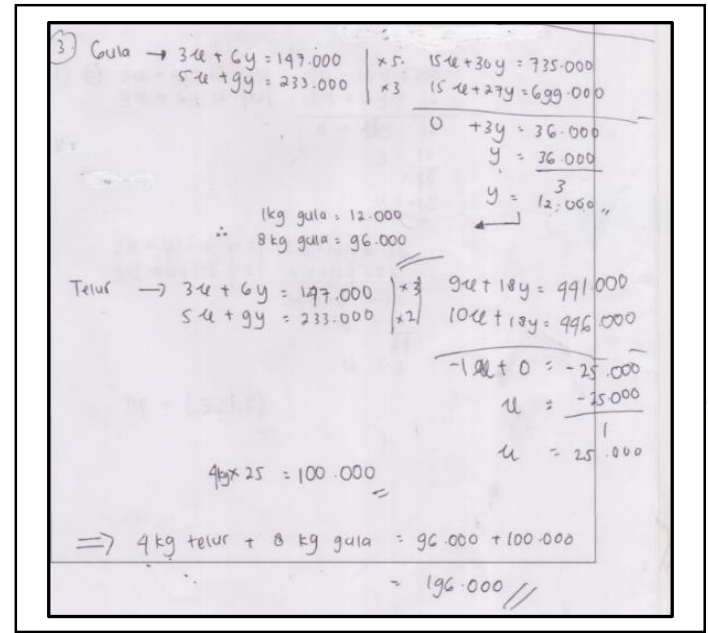

$P \quad$ : What is the meaning of $x$ and $y$

SIM : $x$ is the price per $k g$ of eggs and $y$ is the price per kg of sugar.

$P \quad:$ What is asked about this problem?

SIM : $4 x+8 y . "$.

$P \quad$ : What method did you use to solve problem for number 3 ?

SIM : Used the elimination method to determine the value of $y$ is 12.000 and determine value of $x$ is 25.000. Then, multiplying the value of $y$ (price of $1 \mathrm{~kg}$ sugar) by 8 and was obtained the price of $8 \mathrm{~kg}$ sugar is 96.000. Then, multiplying the value of $x$ (price of $1 \mathrm{~kg}$ egg) by 4 and was obtained the price of $12 \mathrm{~kg}$ eggs is 100.000. So the price of $4 \mathrm{~kg}$ eggs and $8 \mathrm{~kg}$ sugar is 196.000 .

From description above it can be seen the final scheme subject of the concept linear equation system of two variables is being able to use his knowledge on the stage of action, process, and object to solve a story question, then understand rules or formulas that need to be used to solve story question, and can explain back the way it was used.

\section{Case 2 - Reflective Subject}

\section{a. Action Stage}

Based on the results of the answer sheets, then analyzed by interview can be seen that subject explains definition of linear equation system of two variables correctly. Subject explains general form of linear equation system of two variables with information correctly. Subject determines example and non example correctly. Subject determines a value is solution of linear equation system of two variables or not and give a reason correctly. This is relevant to the study of Parraguez and Asuman (2009) that the action stage is when someone can show calculations and transformations of mathematical objects, such as substituting number variables in formulas.

Table 6. Reflective Subject Answer at Action Stage

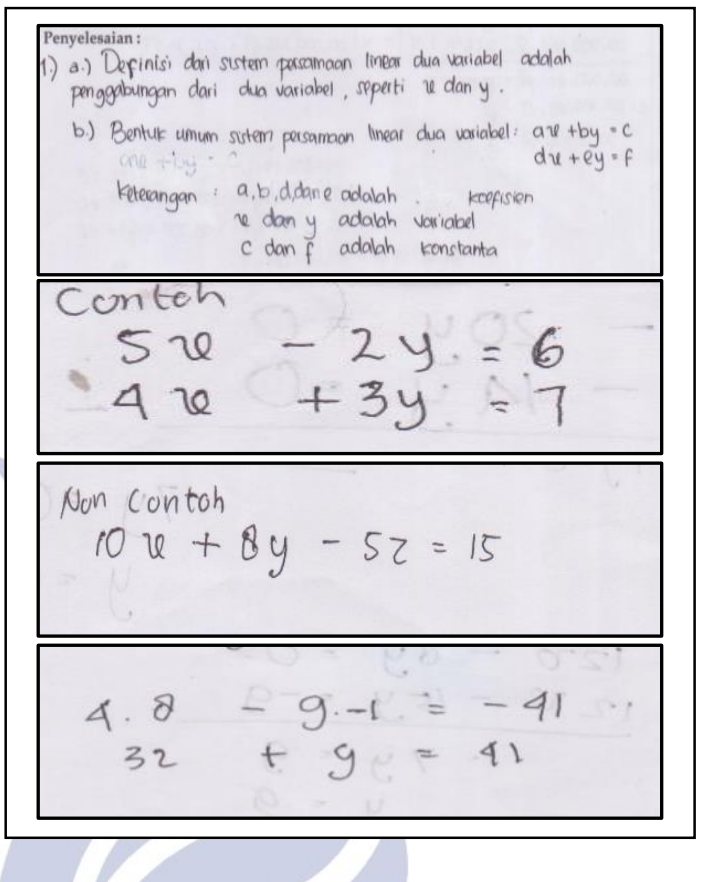

$P \quad$ : What do you know about the definition of linear equation system of two variables?

SRE : Linear equation system of two variables is combination of 2 linear equations of two variables that have a relationship.

$P \quad$ : What term of coefficients?

SRE: Cannot be zero.

$P$ : All variables, coefficients, and constants in linear equation system of two variables are number?

SRE : Real number.

$P \quad$ : Give example and non example from linear equation system of two variables?!

SRE : Example

$$
\begin{aligned}
& 5 x-2 y=6 \\
& 4 x+3 y=13 \\
& \text { Non example } \\
& 10 x+8 y-5 z=15
\end{aligned}
$$

$P:$ Are $(8,-1)$ the solution set of

$4 x-9 y=-41 \ldots(1)$

$3 x-4 y=20 \ldots(2) ?$

SRE : $4(8)-9(-1)=-41$

$$
\begin{gathered}
32+9=41 \\
-41 \neq 41
\end{gathered}
$$

So, not solution.

From description above, it can be seen that initial scheme by subject about linear equation system of two variables concept are explains definition correctly, explains general form with the information and conditions correctly, determines example and non example of linear correctly. 


\section{b. Process Stage}

Based on the results of the answer sheets, then analyzed by interview can be seen that subject determines and explains solution for number $2 \mathrm{a}$ correctly used elimination and substitution methods. Subject determines and explains solution for number $2 b$ correctly used graph method, initially used elimination method, subject needs more time to obtain conclusions from the answers. This is in line with Kagan (1966) that subject of reflective cognitive style requires more time to decide about validity of solution. Subject determines and explains solution for number $2 \mathrm{c}$ correctly used elimination method. This is in line with Dubinsky and McDonald (2001) that the stage of the process occurs when an individual reflexes in taking action, he can pass step by step in his thinking.

Table 7. Reflective Subject Answer at Process Stage

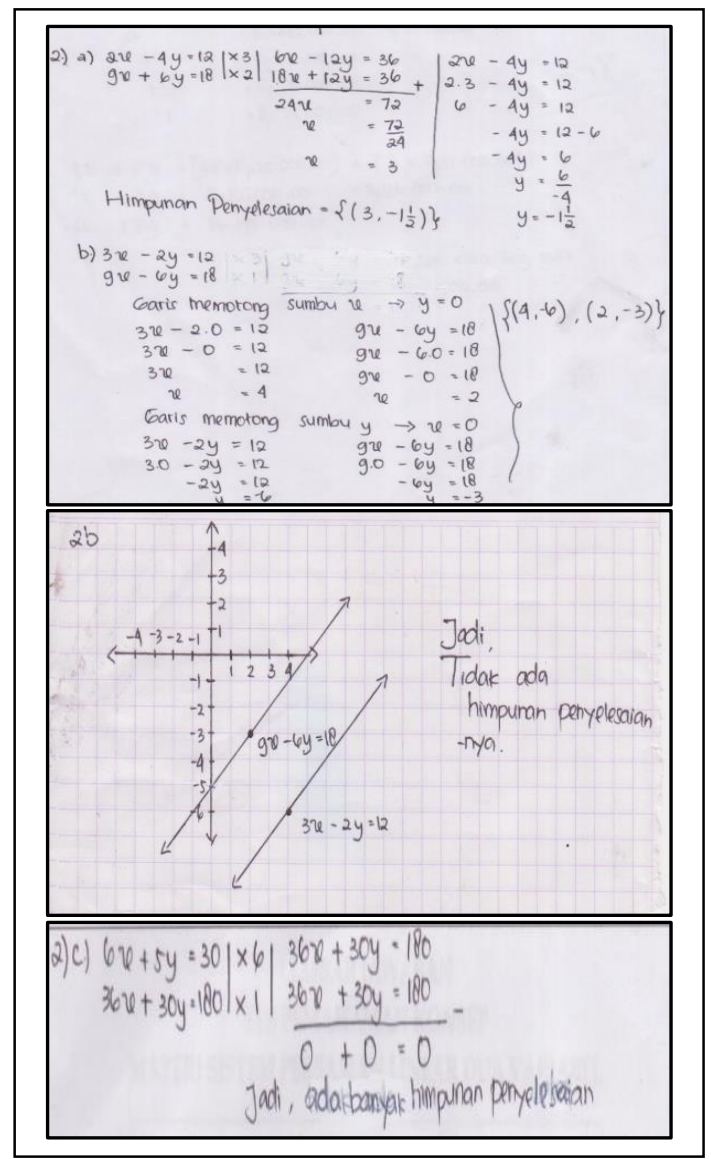

$P \quad$ : How to determine solution set for question number $2 a$ ?

SRE : Used the elimination method to determine the value of $x$, used the substitution method to determine the value of $y$. The value of $x$ is 3, and the value of $y$ is $-1 \frac{1}{2}$. So solution set is $(3$, $\left.1 \frac{1}{2}\right)$.

$P \quad$ : How to determine solution set for question number $2 b$ ?
SRE: Used the elimination method and the result is $0=18$ even though $0 \neq 18$, so there is no solution set.

$P \quad$ : How to determine solution set for question number $2 c$ ?

SRE : Used the elimination method, but the answer I got was precisely $0=0$, so there are many solutions set.

\section{c. Object Stage}

Based on the results of the answer sheets, then analyzed by interview can be seen that subject determines the graphic form of each linear equation system of two variables incorrectly based on the solutions set. Subject was initially confused to determines the characteristics of each linear equation system of two variables based on the solutions set. Subject also did not know if solution was affected by comparison of coefficients in each linear equation system of two variables, after explained, finally subject could make a comparison coefficients based on general form of linear equation system of two variables.

Table 8. Reflective Subject Answer at Object Stage

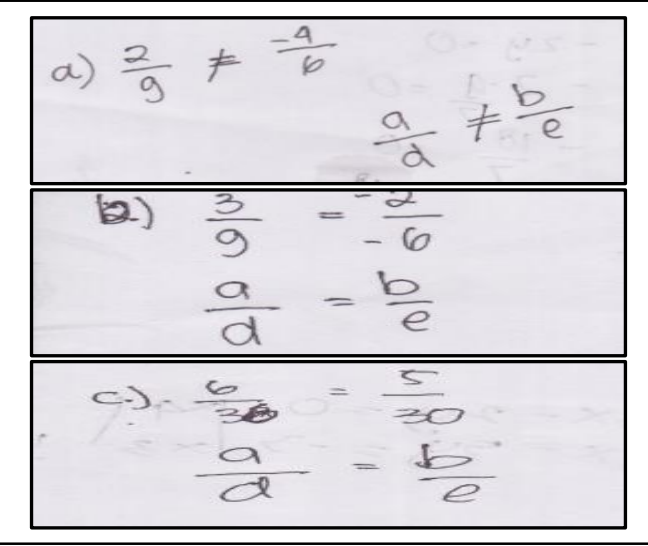

$P \quad:$ What is the conclusion of each linear equation system of two variables characteristic for questions numbers $2 a$, $b, c$ ?

SRE: If linear equation system of two variables have one solution set so the graph intersects and applies $\frac{a}{d} \neq \frac{b}{e}$. if linear equation system of two variables don't have solution set so the graph is parallel and applies $\frac{a}{d}=\frac{b}{e}$, if linear equation system of two variables have many solutions sets so the graph coincides and applies $\frac{a}{d}=\frac{b}{e}$.

Subject determines the characteristics of each linear equation system of two variables for numbers $2 a$, b, c based on solutions set, graphical form, and coefficients comparison. 


\section{d. Schema Stage}

Based on the results of the answer sheets, then analyzed by interview can be seen that subject knows what is known and asked about question. Subject changes verbal sentence that is known in into a mathematical sentence. Subject considers what is $t$ and g. Subject wrote what asked in the problem into a mathematical sentences. Subject use elimination method from mathematical model to determine price of $1 \mathrm{~kg}$ of sugar and $1 \mathrm{~kg}$ of egg then determine price of 4 $\mathrm{kg}$ of sugar and $8 \mathrm{~kg}$ of eggs. Subject looks detailed in solving story question. This is relevant to the study of Warli (2010) that reflective cognitive style students have better creativity than impulsive cognitive style students, so that reflective cognitive style students in problem solving are made varied, clear, and can be understood by others.

Table 9. Reflective Subject Answer at Schema Stage

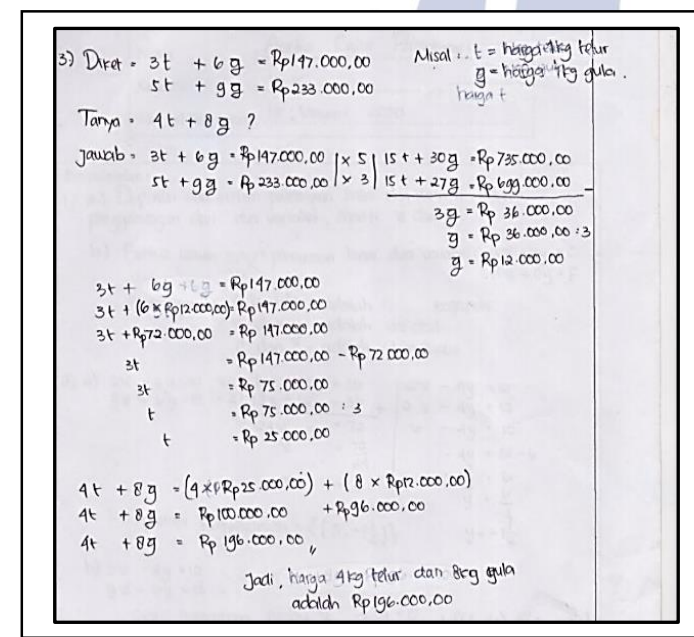

$P \quad:$ What method did you use to solve problem for number 3 ?

SRE: Used the elimination method to determine the value of $g$ is 12.000 and determine the values of $t$ is 25.000. Then, substitute the value of $g$ and $t$ in $4 t+8 g$. So the price of $4 \mathrm{~kg}$ eggs and $8 \mathrm{~kg}$ sugar is 196.000 .

From description above it can be seen that final scheme subject of linear equation system of two variables is being able to use his knowledge on stage of action, process, and object to solve a story question, then understand rules or formulas that need to be used, and can explain back the way it was used.

\section{CONCLUSION}

On the action stage, impulsive cognitive style student define linear equation system of two variables correctly, explain general form of linear equation system of two variables correctly, determines example and non example correctly, determine a value solution set or not correctly. On the process stage, impulsive cognitive style determines solutions set of linear equation system of two variables correctly. On the object stage, impulsive cognitive style student determines characteristics of linear equation system of two variables based on solution set, graphical form, and coefficient comparisons correctly. On the schema stage, impulsive cognitive style student could convert verbal sentences that are known and asked into mathematical sentences, use certain procedures to solve question correctly, but student look less detail in solving question.

On the action stage, reflective cognitive style student define linear equation system of two variables correctly, explain general form correctly, determine example and non example correctly, determine a value is the solution set or not correctly. On the process stage, reflective cognitive style student determines solution set of linear equation system of two variables correctly. On the object stage, reflective cognitive style student determines characteristics of linear equation system of two variables based on solutions set, graphical form, and coefficient comparisons correctly. On the schema stage, reflective cognitive style student could convert verbal sentences that are known and asked to question into mathematical sentences, use certain procedures to solve question correctly.

\section{SUGGESTIONS}

Based on the results of the study, the suggestions is a listed below.

1. The result of the study indicates that there are differences between impulsive and reflective students in understanding concepts. Reflective students tend to be careful in determining decisions and details in solving problems so it requires more work time than impulsive students. For mathematics instructors, it is recommended to pay attention students' cognitive styles.

2. For other researchers who will conduct research in order to describe students' understanding based on APOS theory, it is recommended that they review from other various aspects, such as gender, learning styles, mathematical abilities, and so on.

\section{REFERENCES}

Abubakar, H. 2016. Influence of Reflective and Impulsive Cognitive Styles on Academic Self-Efficacy among Senior Secondary Students in Kaduna State. Dissertation. Nigeria: Ahmadu Bello University. (Online), (http://kubanni.abu.edu.ng, accessed on 17 March 2019).

Desmita. 2009. Psikologi Perkembangan Peserta Didik. Bandung : PT Remaja Rosdakarya.

Dubinsky, ED. 2000. Using a Theory of Learning in College Mathematics Course, (Online), 
(http://www.bham.ac.uk/ctimath/Talum12.htm, accessed on 20 October 2019).

Dubinsky, ED and Michael A. McDonald. 2001. APOS : A Constructivist Theory of Learning in Undergraduate Mathematics Education Research, (Online),(https://link.springer.com/chapter/10.1007/0306-47231-7_25, accessed on 10 August 2019).

Juliana and Jafar. 2017. Pemahaman Siswa terhadap Konsep Sistem Persamaan Linear Dua Variabel (SPLDV). (Online), (https://docplayer.info/71711052Pemahaman-siswa-terhadap-konsep-sistem persamaan-linear-dua-variabel-spldv.html, accessed on 15 February 2020).

Kagan, Jerome. 1966. "Reflection-Impulsivity: The Generality and Dynamics Of Conceptual Tempo". Journal of Abnormal Psycholog. Vol. 71 (1): pp 17-24.

Kurnawati, D et al. 2018. Pemahaman Konseptual Siswa Dalam Materi Sistem Persamaan Linear Dua Variabel, (Online), (http://jurnal.untan.ac.id/index.php/jpdpb/article/view File/31954/75676580543, accessed on 20 October 2019).
Parraguez, Marcela and Asuman, Oktaç. 2009. Construction of The Vector Space Concept from TheViewpoint of APOS, (Online), (https://core.ac.uk/download/pdf/82157770.pdf, accessed on 5 September 2019).

Piaget, J. dan Inhelder, B. 1974. The Child's Construction of Quantities. London: Routledge \& Kegan Paul.

Rahmawati, Suci. 2018. Analisis Tingkat Pemahaman Siswa Berdasarkan Teori APOS (Action, Process, Object, Scheme) Pokok Bahasan Relasi dan Fungsi pada Siswa Kelas VIII-A di SMP Negeri 4 Jember, (Online),(https://repository.unej.ac.id/handle/1234567 89/88917, accessed on 10 August 2019).

Uno, Hamzah B. 2008. Orientasi Baru dalam Psikologi Pembelajaran. Jakarta: Bumi Aksara.

Warli. 2010. Profil Kreativitas Siswa yang Bergaya Kognitif Reflektif dan Siswa yang Bergaya Kognitif Impulsif dalam Memecahkan Masalah Matematika. Disertasi tidak dipublikasikan. Surabaya: PPs Universitas Negeri Surabaya. 